\title{
The Impact of Different Seamline Production Methods on the Production of Orthophoto Mosaic in Urban Area
}

\author{
Hakan KARABÖRK ${ }^{1}$, Mehmet Ozan FAKIOĞLU ${ }^{2}$ \\ ${ }^{1}$ Selçuk University, Engineering faculty, Geomatics Engineering Department, Konya. \\ ${ }^{2}$ Mescioğlu Engineering and consultancy \\ e-posta: hkarabork@selcuk.edu.tr
}

Geliş Tarihi: 18.02.2017 ；Kabul Tarihi: 17.08.2017

\section{Farklı Dikiş Çizgisi Üretim Yöntemlerinin Meskûn Alanda Ortofoto Mozaik Üretimine Etkisi}

Keywords

Photogrammetry;

Orthophoto;

Seamline; Ortho

Mosaic

\section{Anahtar kelimeler} Fotogrametri;

Ortofoto; Dikiş çizgisi; Ortofoto Mozaik

\begin{abstract}
Evolving software and image acquisition systems have reduced orthophoto production time, positively impacted product quality and reduced production costs. Quality of the orthophoto production process is influenced by the exterior orientation parameters and the digital elevation model. The seamline used in the mosaicking is also affected by the mathematical methods used.It is certain that determining the most accurate mathematical method to be used in seamline production will reduce time in orthophoto production and increase product quality.

In the test area (urban area) determined in this study,mosaic production withobject-based recognition, adaptive feathering, smart seams method and the closest-to-camera-center methods have been realized using images with a ground sampling distance (GSD) of $30 \mathrm{~cm}$ and $10 \mathrm{~cm}$. As a result, the most successful results have been obtained using object-based recognition method.
\end{abstract}

\section{Özet}

Gelişen yazılım ve görüntü alım sistemleri, ortofoto üretim zamanını azaltmış, ortofoto kalitesini artırmış ve yapım maliyetinidüşürmüştür. Ortofoto üretim işleminin kalitesini, dış yöneltme parametreleri ve sayısal yükseklik modelleri etkilemektedir. Mozaikleme işleminde kullanılacak dikiş çizgisinin kalitesini ise kullanılan matematiksel yöntemleretkilemektedir. Dikiş çizgisi üretiminde kullanılacak en doğru matematik yöntemi belirlemek, ortofoto üretim süresini azaltacağı ve ortofoto kalitesini artıracağı beklenmektedir.

Bu çalışmada belirlenen test alanında (meskun) yer örnekleme aralı̆̆ $30 \mathrm{~cm}$ ve $10 \mathrm{~cm}$ olan görüntüler kullanılarak nesne algılama, uyumlu saydamlaştırma, akıllı dikiş ve en yakın kamera merkezi yöntemleri ile mozaik üretimi gerçekleştirilmiştir. Sonuç olarak, en başarılı sonuçlar nesne algılama yöntemiyle elde edilmiştir. 


\section{INTRODUCTION}

As a result of the intensive use of computer technology in photogrammetry, it is easy to solve difficult and complex problems. Mosaic production is started by having created a seamline from ortho images. Multiple seamline production methods are available for mosaic production. There have been numerous studies on this subject. Gray level values were taken into account at the work to be described as the first starting point of seamline production method and the line drawing was done by selecting the seamline according to the edge measurement which calculates the sum of the omega differences between the two images. Method of feathering for sudden gray level changes between two edgesis deemed suitable(Milgram, 1975). In another study, it has been shown that a wavelet-based algorithm is very effective and removing the gray seamlinecan be gained satisfactory results (Zhu et al., 2000). A seam-line optimized method based on difference image and gradient imageis used in the ongoing research process for seamline production (Pan et al., 2011). To prevent discontinuity in the mosaic, seamline optimization based on ground objects classes for orthoimage mosaickingis presented (Pan et al., 2017). In another study, a new method is proposed to determine the seamline based on semantic segmentation (Saito et al., 2015). In order to assist in the selection of the seamlines, it has been studied using various vector-formatted data such as vector roadsdrawn by manual methods (WAN et al., 2012). In the mosaicking of ortho image, a new method for seamline recognition is introduced using the region change rate-driven seamline determination method (Pan et al., 2015). A new automatic seamline selection algorithm together with a digital surface model have been proposedin order to minimize visual discontinuities in mosaic products, to avoid high ground objects and to select automatically seamlines (Chen et al., 2014). There is a problem in urbanareas in terms of visual in the final product. For this reason, it is very important to determine the seamline production method. The aim is to ensure that the produced seamline passes through the ground without touching any objectwhen the mosaic is controlled after the production of the seamline. A number of studies have been carried out in theseamline production for urban area (Chen et al., 2014; Chon et al., 2010; Pan et al., 2011; Pan et al., 2015; Pan et al., 2017; Saito et al., 2015). In this study, the most difficult, dense, concentrated and narrow regions of the urban area will be tested for selecting the seamline production method.

In this study, the works have been carried out with overlapping ortho images with different sampling distances in the same area. It is aimed to determine the advantages and disadvantages of seamline methods for mosaic products produced from $10 \mathrm{~cm}$ and $30 \mathrm{~cm}$ GSDortho images in irregular dense areas.

\section{Material and Method}

Block selection is done according to GSD, density and number of buildings in test area. $10 \mathrm{~cm}$ GSD and $30 \mathrm{~cm}$ GSD overlapped ortho images were used for the same irregular dense urban area. In this study, Trimble inpho OrthoVista and GeoMedia Professional OrthoPro software had been used as demo licensed.

\subsection{Data Source}

The data of Bursa M5 project and the data of whole Turkey orthophoto production LPIS project were used in the research.

\subsection{Determination of Urban Area}

In the photogrammetric blocks used in this study, the test areas with two different ground sampling distances were created in the same area under the following criteria (Table 1 ).

$10 \mathrm{~cm}$ and $30 \mathrm{~cm}$ GSD ortho images of selected blocks and test areas are shown in the red area (Figure 1). 
Table 1. Selected Blocks' Information

\begin{tabular}{|c|c|c|}
\hline Block No & Block_C2 & Block_25 \\
\hline Region & Marmara & Marmara \\
\hline Camera & UltraCamX & DMCII-250 \\
\hline Block Area (Km2) & $9261 \mathrm{Km}^{2}$ & $79.76 \mathrm{Km}^{2}$ \\
\hline Block Geometry & Rectangle & Rectangle \\
\hline $\begin{array}{l}\text { Block Adjustment Result } \\
\text { (Sigma Value) }\end{array}$ & 1.7 Micron & 1.4 Micron \\
\hline Number of GCPs & 60 & 19 \\
\hline Photo Acquisition Date & $05 / 15$ & $09 / 2016$ \\
\hline Number of Photos in Block & 3807 & 281 \\
\hline Flight Height (Feet) & $13670 \mathrm{FT}$ & $6561.6 \mathrm{FT}$ \\
\hline Working Region and Type & $\begin{array}{l}\text { Irregular dense } \\
\text { residential area }\end{array}$ & $\begin{array}{l}\text { Irregular dense } \\
\text { residential area }\end{array}$ \\
\hline $\begin{array}{l}\text { Ground Sampling Distance } \\
\text { (GSD) }\end{array}$ & $30 \mathrm{~cm}$ & $10 \mathrm{~cm}$ \\
\hline $\begin{array}{l}\text { Number of Images to be } \\
\text { Tested in Mosaic Production }\end{array}$ & 2 & 2 \\
\hline
\end{tabular}

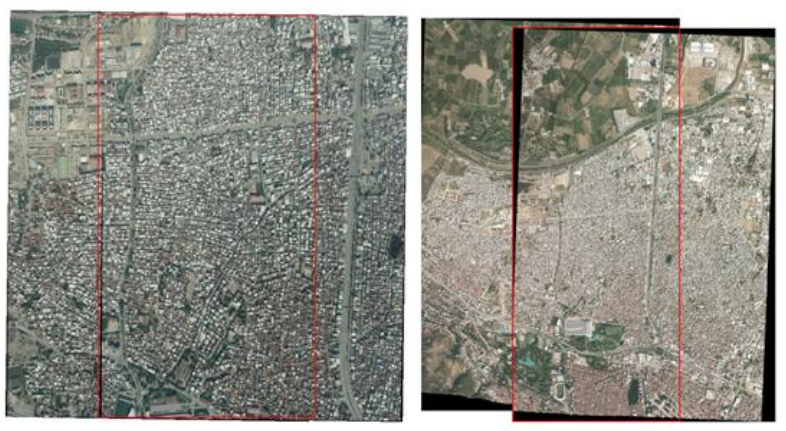

Figure 1: Overlapping ortho images with different ground sampling distances to be used in seamline production and overlapping areas

\subsection{Methods}

The seamline is a process step that determines areas will be included in the mosaic through orthophoto. The seamlines are drawn along the exterior outlines of the the projection center in image space and on the approximate centerline of each overlap area. The seamline thus forms a closed area (Figure 2). The general approach of software in seamline production is that each has its own unique characteristics. The seamline production methods start from a reference point initially according to overlapping areas and pass lines according to the gray values of the images.
They move and work this way as a basic approach. Furthermore, they operate according to given input parameters and algorithm for object-recognition, and forcibly bypassing seamlines from high dense areas (Hexagonal Geospatial, 2015; Trimble Inpho 2017).
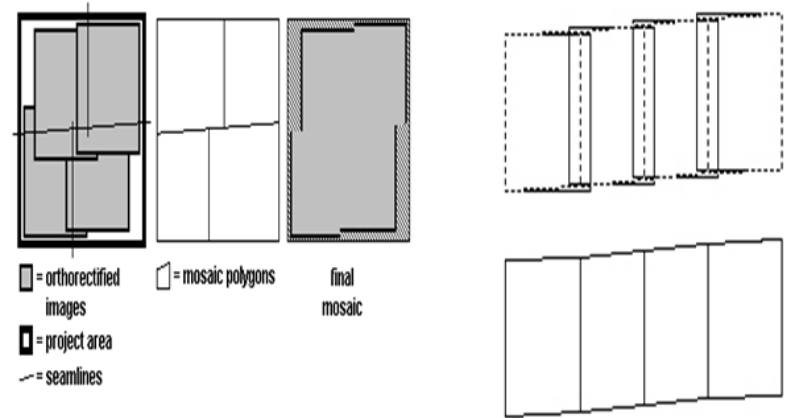

Figure 2: Seamline production from overlapping ortho images

The seamline production plays a very important role into the output mosaic. Generally, this problem is encountered mostly in the urbanareas. According to the result of the researches, there have been numerous academic studies on the fact that the seamline does not pass over the building while mosaic production is being carried out in the urbanarea. It is because the high-quality objectare required to be expressed geometrically and visually in the output mosaic. Otherwise, it causes tearing, twisting, twitching, ghosting and tilting in the image. In the selected irregularly dense urbanarea, the seamline production was carried out from 10 $\mathrm{cm}$ and $30 \mathrm{~cm}$ GSD overlapping ortho images with object based recognition, adaptive feathering, smart seams method and the closest-to-cameracenter methods and they were tested in mosaic products.

The closest-to-camera-center method allows you to generate seamlines for ortho imagery from different sources. It assumes that the orthos are all approximately the same size. It allows gaps in the data and does not require that the source photos be organized in strips with uniform flight lines. The smart seams method finds a shortest-path vector between overlapping orthos that is based on the computation of least pixel-intensity difference 
(Hexagonal Geospatial, 2015). The adaptive feathering method merges individual input images into a seamless mosaic. The method automatically computes a "blending function", which determines how to combine the individual input images into the output mosaic. A blending sharpness parameter controls the steepness of the blending function, which in turn controls the default width of the blending function. In areas of complex relief displacement (e.g. buildings), the blending function is automatically made steeper, so that the imageto-image transition occurs more quickly in these regions. Object based recognition method is better adapted to urban areas and it can also be used in different areas such as mixed and rural. The Object recognition function is in general slightly faster with seam lines avoiding more features, like buildings, especially in urban areas. (Trimble Inpho, 2017).

\section{RESULT and DISCUSSION}

In selected irregular dense urbanareas, the seamline was produced from two ortho images with $30 \mathrm{~cm}$ GSD with object based recognition, adaptive feathering, smart seams method and closest-to-camera-center methods. The drawing of the seamline is shown in the produced mosaic area and the drawing of the seamline in the output mosaic is shown after the produced seamline (Figures. 3 and 4).

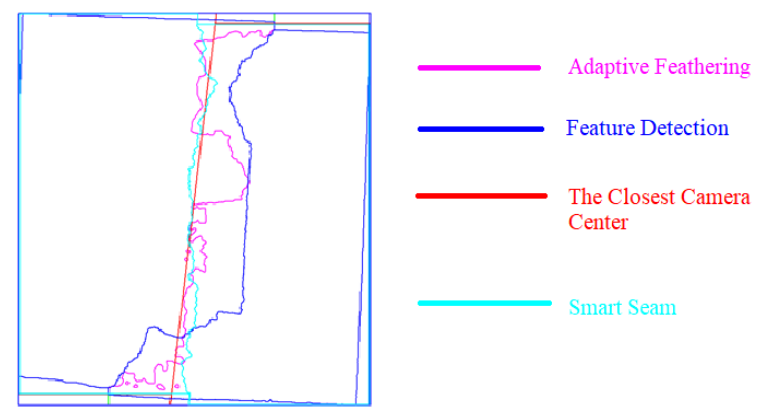

Figure 3. Seamlines produced from two ortho images with $30 \mathrm{~cm}$ ground sampling distance
Among mosaic products $(30 \mathrm{~cm}$ ground sampling distance), the seamline produced from the object based recogtinion method follows (blue) path, the seamline produced fromthe closest-to-cameracenter method and the contacted areas are shown in (red), the seamline produced from the adaptive feathering method and the contacted areas are shown in (pink), the seamline produced from the smart seams method and the contacted areas are shown in (turquoise) (Figure 4).

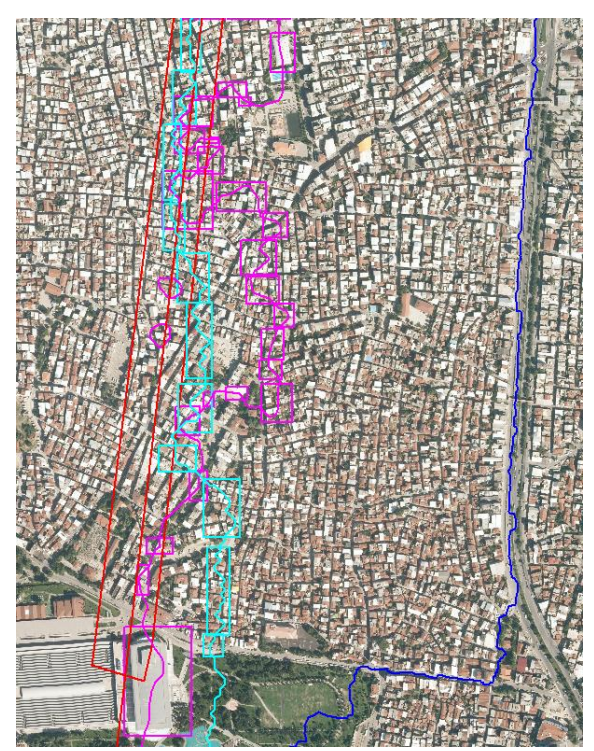

Figure 4. Transition of the seamline in the result mosaic after the created seamline

The results of the seamline methods produced for the overlapping ortho images with $30 \mathrm{~cm}$ ground sampling distance in irregular dense urban area are presented according to the determined parameters (Table2). 
Table 2. Results according to parameters determined for seamline production from two ortho images with $30 \mathrm{~cm}$ ground sampling distance.

\begin{tabular}{|c|c|c|c|c|c|c|c|c|c|c|}
\hline $\begin{array}{l}\text { Seamline } \\
\text { Production } \\
\text { Time (Sec) }\end{array}$ & $\begin{array}{l}\text { Seamline } \\
\text { Production } \\
\text { Method }\end{array}$ & $\begin{array}{l}\text { Need for } \\
\text { Seamline } \\
\text { Editing }\end{array}$ & $\begin{array}{l}\text { Mosaic } \\
\text { Production } \\
\text { Time (Min) }\end{array}$ & $\begin{array}{l}\text { Seamline } \\
\text { Export- } \\
\text { Import } \\
\text { Feature }\end{array}$ & $\begin{array}{l}\text { Color } \\
\text { Balance of } \\
\text { Software } \\
\text { in Mosaic } \\
\text { Production }\end{array}$ & $\begin{array}{l}\text { Does the } \\
\text { Software } \\
\text { Have a } \\
\text { Seamline } \\
\text { Editing } \\
\text { Menu? }\end{array}$ & $\begin{array}{l}\text { dxf-shp } \\
\text { Attaching } \\
\text { Feature } \\
\text { for } \\
\text { Seamline } \\
\text { Guidance }\end{array}$ & $\begin{array}{l}\text { Overlapping } \\
\text { Area } \\
\text { Between } \\
\text { Images } \\
\left(\mathrm{Km}^{2}\right)\end{array}$ & $\begin{array}{l}\text { Number } \\
\text { of } \\
\text { Buildings } \\
\text { / } \\
\text { Structures } \\
\text { in the } \\
\text { Study } \\
\text { Area }\end{array}$ & $\begin{array}{l}\text { How Many } \\
\text { Buildings } \\
\text { did } \\
\text { Seamline } \\
\text { Pass Over } \\
\text { After } \\
\text { Production } \\
\text { ? }\end{array}$ \\
\hline 13 & $\begin{array}{l}\text { Object } \\
\text { based } \\
\text { recognition }\end{array}$ & NO & 3.03 & YES & $\begin{array}{l}\text { VERY } \\
\text { GOOD }\end{array}$ & YES & YES & $9.384 \mathrm{Km}^{2}$ & 12886 & 0 \\
\hline 9 & $\begin{array}{l}\text { Adaptive } \\
\text { Feathering }\end{array}$ & YES & 3.38 & YES & $\begin{array}{l}\text { VERY } \\
\text { GOOD }\end{array}$ & YES & YES & $9.384 \mathrm{Km}^{2}$ & 12886 & 132 \\
\hline 11 & $\begin{array}{l}\text { Smart } \\
\text { Seams }\end{array}$ & YES & 1.37 & YES & GOOD & NO & NO & $9.384 \mathrm{Km}^{2}$ & 12886 & 151 \\
\hline 11 & $\begin{array}{l}\text { Closest-to- } \\
\text { Camera- } \\
\text { Center }\end{array}$ & YES & 1.37 & YES & GOOD & NO & NO & $9.384 \mathrm{Km}^{2}$ & 12886 & 136 \\
\hline
\end{tabular}

In the irregular dense urbanarea, the seamline was produced from two ortho images with $10 \mathrm{~cm}$ GSD with object based recognition, adaptive feathering, smart seams method and closest-to-camera-center methods. The drawing of the seamline is shown in the produced mosaic area and the drawing of the seamline in the output mosaic is shown after the produced seamline (Figures. 5 and 6).

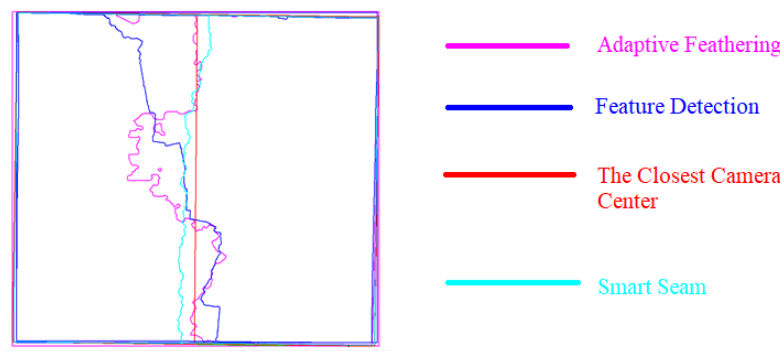

Figure 5. Seamlines produced from two ortho images with $10 \mathrm{~cm}$ ground sampling distance

Among mosaic products $(10 \mathrm{~cm}$ ground sampling distance); the seamline produced from object based recognition method follows (blue) path, the seamline produced from closest-to-camera-center method and the contacted areas are shown in (red), the seamline produced from the adaptive feathering method and the contacted areas are shown in (pink), the seamline produced from the smart seams method and the contacted areas are shown in (turquoise) (Figure 6).

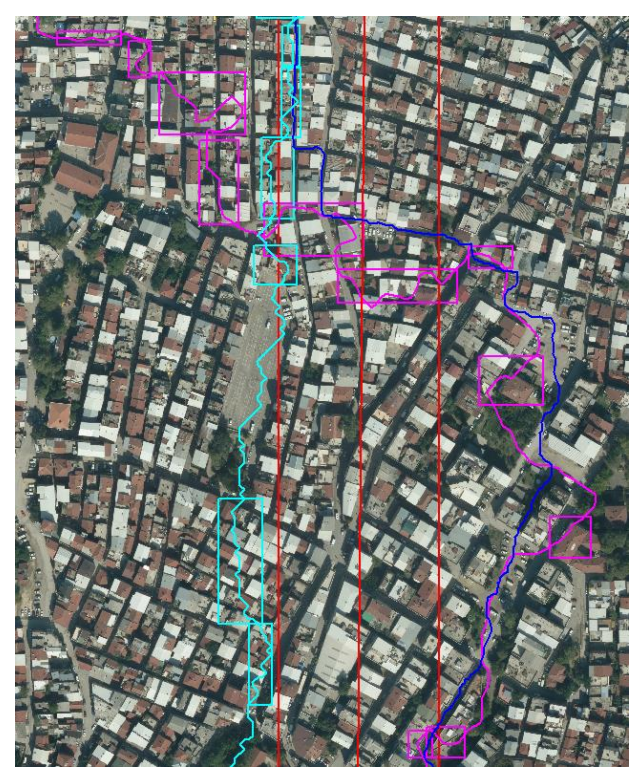

Figure 6. Transition of the seamline in the result mosaic after the created seamline

The results of the seamline methods produced for the overlapping ortho images with $10 \mathrm{~cm}$ ground sampling distance in irregular dense urban area arepresented according to the determined parameters (Table 3) 
Table 3. Results according to the parameters determined for seamline production from two ortho images with $10 \mathrm{~cm}$ ground sampling distance

\begin{tabular}{|c|c|c|c|c|c|c|c|c|c|c|}
\hline $\begin{array}{l}\text { Seamline } \\
\text { Production } \\
\text { Time (Sec) }\end{array}$ & $\begin{array}{l}\text { Seamline } \\
\text { Production } \\
\text { Method }\end{array}$ & $\begin{array}{c}\text { Need for } \\
\text { Seamline } \\
\text { Editing }\end{array}$ & $\begin{array}{c}\text { Mosaic } \\
\text { Production } \\
\text { Time (Min) }\end{array}$ & $\begin{array}{l}\text { Seamline } \\
\text { Export- } \\
\text { Import } \\
\text { Feature }\end{array}$ & $\begin{array}{l}\text { Color } \\
\text { Balance of } \\
\text { Software } \\
\text { in Mosaic } \\
\text { Production }\end{array}$ & $\begin{array}{l}\text { Does the } \\
\text { Software } \\
\text { Have a } \\
\text { Seamline } \\
\text { Editing } \\
\text { Menu? }\end{array}$ & $\begin{array}{l}\text { dxf-shp } \\
\text { Attaching } \\
\text { Feature } \\
\text { for } \\
\text { Seamline } \\
\text { Guidance }\end{array}$ & $\begin{array}{l}\text { Overlapping } \\
\text { Area } \\
\text { Between } \\
\text { Images } \\
\text { (Km2) }\end{array}$ & $\begin{array}{c}\begin{array}{c}\text { Number } \\
\text { of }\end{array} \\
\text { Buildings } \\
\text { / } \\
\text { Structures } \\
\text { in the } \\
\text { Study } \\
\text { Area }\end{array}$ & $\begin{array}{c}\text { How Many } \\
\text { Buildings } \\
\text { did } \\
\text { Seamline } \\
\text { Pass Over } \\
\text { After } \\
\text { Production } \\
?\end{array}$ \\
\hline 26 & $\begin{array}{l}\text { Object } \\
\text { based } \\
\text { recognition }\end{array}$ & NO & 11.02 & YES & $\begin{array}{l}\text { VERY } \\
\text { GOOD }\end{array}$ & YES & YES & $1.937 \mathrm{Km}^{2}$ & 6084 & 0 \\
\hline 16 & $\begin{array}{l}\text { Adaptive } \\
\text { Feathering }\end{array}$ & YES & 11.1 & YES & $\begin{array}{l}\text { VERY } \\
\text { GOOD }\end{array}$ & YES & YES & $1.937 \mathrm{Km}^{2}$ & 6084 & 112 \\
\hline 11 & $\begin{array}{l}\text { Smart } \\
\text { Seams }\end{array}$ & YES & 2.23 & YES & GOOD & NO & NO & $1.937 \mathrm{Km}^{2}$ & 6084 & 133 \\
\hline 11 & $\begin{array}{l}\text { Closest-to- } \\
\text { Camera- } \\
\text { Center }\end{array}$ & YES & 2.15 & YES & GOOD & NO & NO & $1.937 \mathrm{Km}^{2}$ & 6084 & 117 \\
\hline
\end{tabular}

The output products of seamline production methods in mosaic produced from test blockin the urban areas and their results specified according to the parameters are described above. Based on these results, the success rates of seamline production methods in irregular dense urban areas are as follows (Tables 4 and 5).

Table 4. Success rates of seamline production methods

\begin{tabular}{|c|c|c|c|c|}
\hline $\begin{array}{l}\text { Seamline Method Used in } \\
\text { Mosaic Production }\end{array}$ & \multicolumn{2}{|c|}{$\begin{array}{l}\text { Object based } \\
\text { recognition }\end{array}$} & \multicolumn{2}{|c|}{$\begin{array}{l}\text { Adaptive } \\
\text { Feathering }\end{array}$} \\
\hline Working Region and Type & \multicolumn{2}{|c|}{$\begin{array}{l}\text { Irregular Dense } \\
\text { Residential }\end{array}$} & \multicolumn{2}{|c|}{$\begin{array}{l}\text { Irregular Dense } \\
\text { Residential }\end{array}$} \\
\hline GSD $(\mathrm{cm})$ & $30 \mathrm{~cm}$ & $10 \mathrm{~cm}$ & $30 \mathrm{~cm}$ & $10 \mathrm{~cm}$ \\
\hline $\begin{array}{l}\text { Number of Buildings and } \\
\text { Structures }\end{array}$ & 12886 & 6084 & 12886 & 6084 \\
\hline $\begin{array}{l}\text { Number of Structures } \\
\text { (Seamline Contacted) }\end{array}$ & 0 & 0 & 132 & 112 \\
\hline $\begin{array}{l}\text { Number of Structures } \\
\text { (Seamline Did not } \\
\text { Contact) }\end{array}$ & 12886 & 6084 & 12754 & 5972 \\
\hline Success Rate & $100.00 \%$ & $100.00 \%$ & $98.98 \%$ & $98.16 \%$ \\
\hline
\end{tabular}

Table 5. Success rates of seamline production methods

\begin{tabular}{lcccc}
\hline $\begin{array}{l}\text { Seamline Method Used in } \\
\text { Mosaic Production }\end{array}$ & \multicolumn{2}{c}{ Smart Seam } & \multicolumn{2}{c}{$\begin{array}{c}\text { The Closest } \\
\text { Camera Center }\end{array}$} \\
\hline $\begin{array}{l}\text { Working Region and Type } \\
\text { Irregular Dense } \\
\text { Residential }\end{array}$ & \multicolumn{3}{c}{$\begin{array}{c}\text { Irregular Dense } \\
\text { Residential }\end{array}$} \\
$\begin{array}{l}\text { GSD (cm) } \\
\begin{array}{l}\text { Number of Buildings and } \\
\text { Structures }\end{array}\end{array}$ & 12886 & 6084 & 12886 & 6084 \\
$\begin{array}{l}\text { Number of Structures } \\
\text { (Seamline Contacted) }\end{array}$ & 151 & 133 & 136 & 117 \\
$\begin{array}{l}\text { Number of Structures } \\
\text { (Seamline Did not Contact) }\end{array}$ & 12735 & 5951 & 12750 & 5967 \\
\begin{tabular}{l} 
Success Rate \\
\hline
\end{tabular} & $98.83 \%$ & $97.81 \%$ & $98.94 \%$ & $98.08 \%$ \\
\hline
\end{tabular}

Mosaic products were obtained by object based recognition, adaptive feathering, smart seams method and seamline production with the closestto-camera-center methods from two ortho images with $30 \mathrm{~cm}$ ground sampling distances. There were approximately 12,886 buildingss in the area of seamline production of overlapping ortho images. The seamline production times were 13, 9, 11 and 11 seconds, respectively.

The seamline produced in the mosaic did not touch any building as the result of seamline production with object based recognition method while it passed over the buildings of 132 units as the result 
of the adaptive feathering, of 151 units as the result of smart seams method, of 136 units as a result of the closest-to-camera-center method. In the output production, where there was contact with the building units, visual disturbances occurred.Mosaic products were obtained by object based recognition, adaptive feathering, smart seams method and seamline production with the closest-to-camera-center methods from two ortho images with $10 \mathrm{~cm}$ ground sampling distance. There were approximately 6084 buildingsin the area of the seamline production of the overlapping ortho images. Seamline production times were 26, 16, 11 and 11 seconds respectively. The reason why the time difference was so noticeable is that the ortho images obtained from the Geomedia software were introduced to Orthovista software. The seamline produced in the mosaic did not touch any building as the result of seamline production with object based recognition method while it passed over the buildingsof 112 units as the result of the adaptive feathering, of 133 units as the result of smart seams method, of 117 units as a result of the closest-to-camera-center method. In the output, where there was contact with the building sites, visual disturbances occurred.

When compared to other methods, duration of object based recognition method took 2 seconds longer on $30 \mathrm{~cm}$ GSD and 10 seconds longer on $10 \mathrm{~cm}$ GSD on the test areas. If a block consisting 400 photographs is considered; seamline generation time differs 13 and 66 minutes respectively. Editing time of the seamlines which generated by other methods that contacted to buildings would take similar times. As a result, time difference of generating seamlines with object based recognition method will not be considered as important.

Comparing the test areas belonging to $30 \mathrm{~cm}$ and $10 \mathrm{~cm}$ GSD , there were 12886 and 6084 buildings . While the seamline produced by the object based recognition method did not touch any building, the number of contacts with the building areas were close to each other for $30 \mathrm{~cm}$ and $10 \mathrm{~cm} \mathrm{GSD} \mathrm{in}$ other seamline production methods. However, the number of buildings in the test area belonging to $30 \mathrm{~cm}$ GSD was more than twice that of $10 \mathrm{~cm}$ GSD. As a result, the seamlines produced by the object based recognition method in the irregularly dense urbanareas caught the same success as they did not touch any building.

Looking at the results of previous studies, it is obvious that the same success has been achieved and seamline production has been made in a very short time and time has been saved.

\section{CONCLUSION}

In this study, densest and challenging areas of the urban area have been selected and tested.As a result of the seamline production methods in irregular dense urban area being obtained from 10 $\mathrm{cm}$ and $30 \mathrm{~cm}$ GSD overlapping ortho images with adaptive feathering, smart seams methods and the closest-to-camera-center methods, they have warped the buildings in mosaic that they passed over, caused ghosting and twinning. The object based recognition method has provided $100 \%$ success for $10 \mathrm{~cm}$ and $30 \mathrm{~cm} \mathrm{GSD}$ in test areas while other methods have failed in giving the same result. The result success rates of the other seamline production methods are between $97.81 \%$ and $98.98 \%$. When the total number of buildings and the number of buildings contacted by the produced seamlines in the study area are 
considered, this result should not be accepted as unsuccessful. However, when considering the arrangement of the seamlines in the building areas it contacts and re-mosaic production times, $100 \%$ success rate of object based recognition method is foreground and the method is successful. Consequently, it has been seen that the object based recognition method is the most successful method for the production of the seamline in urbanarea.

\section{ACKNOWLEDGMENTS}

In this study, it is utilized from the thesis of Map Eng. Mehmet Ozan FAKIOĞLU

\section{REFERENCES}

Chen, Q., Sun, M., Hu, X., Zhang, Z., 2014, Automatic Seamline Network Generation for Urban Orthophoto Mosaicking with the Use of a Digital Surface Model, Remote Sens. 2014, 6, 12334-12359.

Chon, J., H, Kim., C, Lin., 2010, Seam-Line Determination for Image Mosaicking: A Technique Minimizing the Maximum Local Mismatch and the Global Cost, ISPRS Journal of Photogrammetry and Remote Sensing, 65 (1), 86-92.

Milgram, D.L., 1975, Computer methods for creating photomosaics, IEEE Trans. Comput., 24, 1113-1119.

Pan, J., Wang, M., 2011, A seam-line optimized method based on difference image and gradient image, IEEE., 978-1-61284, 848-8/11.

Pan, J., Wang, M., Li, J., Yuan, S., Hu, F., 2015, Region change rate-driven seamline determination method, ISPRS Journal of Photogrammetry and Remote Sensing, 105,141-154.

Pan, J., Yuan, S., Li, J., Wu, B., 2017, Seamline optimization based on ground objects classes for orthoimage mosaicking, Remote Sensing Letters, 8:3, 280-289.

Saito,S., Arai, R.,Aoki,Y., 2015, Seamline Determination Based on Semantic Segmentation for Aerial Image
Mosaicking, IEEE. Translations and content mining are permitted for academic research only, 3, 28472856.

Zhu, S.L., Yang, X.H., 2000, The seamline removing in the generation of orthophoto maps, International Archives of Photogrammetry and Remote Sensing.,Vol. XXXIIIPart B4, 1247-1251.

Wan, Y., Wang, D., Xiao, J., Lai, X., Xu, J., 2012, Automatic determination of seamlines for aerial image mosaicking based on vector roads alone, ISPRS Journal of Photogrammetry and Remote Sensing, 76, 1-10.

\section{Internet references}

1-https://hexagongeospatial.fluidtopics.net/book, (10.07.2016)

2-http://www.trimble.com/imaging/inpho.aspx, (20.07.2016) 